\title{
Noncoding RNAs that associate with YB-1 alter proliferation in prostate cancer cells
}

\author{
TERESA T. LIU, ${ }^{1,6}$ GUSTAVO ARANGO-ARGOTY, ${ }^{1,6}$ ZHIHUA LI, $^{1,6}$ YUEFENG LIN, ${ }^{1}$ SANG WOO KIM, ${ }^{1}$ \\ ANNE DUECK, ${ }^{2}$ FATIH OZSOLAK, ${ }^{3}$ A. PAULA MONAGHAN, ${ }^{4}{ }^{6}$ GUNTER MEISTER, ${ }^{2}$ DONALD B. DEFRANCO, \\ and BINO JOHN ${ }^{1}$ \\ ${ }^{1}$ Department of Computational and Systems Biology, University of Pittsburgh School of Medicine, Pittsburgh, Pennsylvania 15260, USA \\ ${ }^{2}$ University of Regensburg, Biochemistry I, 93053 Regensburg, Bavaria, Germany \\ ${ }^{3}$ Helicos BioSciences Corporation, Cambridge, Massachusetts 02139, USA \\ ${ }^{4}$ Department of Neurobiology, University of Pittsburgh School of Medicine, Pittsburgh, Pennsylvania 15260, USA \\ ${ }^{5}$ Department of Pharmacology and Chemical Biology, University of Pittsburgh School of Medicine, Pittsburgh, Pennsylvania 15260, USA
}

\begin{abstract}
The highly conserved, multifunctional YB-1 is a powerful breast cancer prognostic indicator. We report on a pervasive role for YB-1 in which it associates with thousands of nonpolyadenylated short RNAs (shyRNAs) that are further processed into small RNAs (smyRNAs). Many of these RNAs have previously been identified as functional noncoding RNAs (http://www.johnlab.org/YB1). We identified a novel, abundant, 3'-modified short RNA antisense to Dicer1 (Shad1) that colocalizes with YB-1 to P-bodies and stress granules. The expression of Shad1 was shown to correlate with that of YB-1 and whose inhibition leads to an increase in cell proliferation. Additionally, Shad1 influences the expression of additional prognostic markers of cancer progression such as DLX2 and IGFBP2. We propose that the examination of these noncoding RNAs could lead to better understanding of prostate cancer progression.
\end{abstract}

Keywords: YB-1; noncoding RNAs; miRNAs; prostate cancer

\section{INTRODUCTION}

Human Y-box binding protein 1 (YB-1) is a multifunctional protein that belongs to the highly conserved superfamily of cold shock domain (CSD) proteins known to bind both DNA and RNA (Kohno et al. 2003). It is involved in many cellular functions including transcription/translation (Didier et al. 1988; Evdokimova et al. 2006), alternative splicing (Stickeler et al. 2001; Dutertre et al. 2010), and mRNA degradation/processing in P-bodies (Evdokimova et al. 2001, 2006; Stickeler et al. 2001). Inverse CAAT motifs, typically localized within promoter regions, serve as binding sites for YB-1. Occupancy of YB-1 at these sites can trigger either transcriptional activation through the recruitment of RNA polymerase II (Spitkovsky et al. 1992) or repression via displacement of bound activator proteins (Van de Putte et al. 2003). YB-1 has also been implicated as a protein partner in the splicing and transport of pre-mRNAs (Deckert et al. 2006; Agafonov et al. 2011). In the cytoplasm, YB-1 is also a component of the messenger ribonucleoprotein (mRNP) complexes formed by human Argonautes (AGO), which

\footnotetext{
${ }^{6}$ These authors contributed equally to this work. Corresponding authors: bino@pitt.edu, dod1@pitt.edu

Article published online ahead of print. Article and publication date are at http://www.rnajournal.org/cgi/doi/10.1261/rna.045559.114.
}

are central to small RNA-mediated silencing (Hammond et al. 2001; Meister et al. 2004; Girard et al. 2006; Höck et al. 2007). In addition to the link between YB-1 and mature microRNAs (miRNAs), YB-1's relatedness to lin-28, a pluripotency factor and a processor of the let-7 miRNA precursor (Moss and Tang 2003; Yu et al. 2007; Viswanathan et al. 2009) suggests that it may have a broader role in small RNA processing and function than previously recognized.

The role of YB-1 in human biology and disease has been most thoroughly examined in cancer. YB-1 expression levels have been shown to correlate with drug resistance and poor patient outcome in various cancers (Bargou et al. 1997). Furthermore, YB-1 may be a more powerful prognostic marker for relapse and survival in breast cancer patients than the commonly used markers Her-2 and estrogen receptor (Habibi et al. 2008). YB-1 has been shown to induce the expression of pro-proliferative genes such as Her-2, EGFR, MDR-1, cyclin A, and cyclin B (Bargou et al. 1997; Ise et al. 1999; Raffetseder et al. 2003; Wu et al. 2006). Specifically in breast cancer, YB-1 has been associated with BRCA1 
mutations as identified by microarray (Sorlie et al. 2003). Finally, YB-1 expression levels have also been shown to correlate with malignant transformation and castrate resistant prostate cancer (Giménez-Bonafé et al. 2004). Although the mechanistic basis for YB-1's role in cancer has not been revealed, it is a partner of the p53 tumor suppressor protein and may therefore influence its many functions in tumor progression (Zhang et al. 2003).

Currently, 50 miRNAs have been associated with prostate cancer; however none of them have been shown to be directly related to disease pathogenesis (Pang et al. 2010). Instead, many miRNAs have been shown to correlate with different grades of prostate cancer and could potentially serve as biomarkers for diagnosis and treatment (Walter et al. 2013). A pilot project to predict RNA binding proteins important to small RNA pathways led us to test whether YB-1 associates with small RNAs in the androgen independent PC-3 prostate cancer cell line. In recent years, various classes of small and long noncoding RNAs have been identified in mammals (Gupta et al. 2010; Meiri et al. 2010; Lai et al. 2013). We found that YB-1 associates with a variety of noncoding RNAs in PC-3 cells. These RNAs correspond to thousands of distinct short YB-1-associated noncoding RNAs (shyRNAs) and their cognate processed YB-1-associated small RNAs (smyRNAs) that primarily match to the $5^{\prime}$ or $3^{\prime}$ terminal regions. Many of the shyRNAs that we identified are also identical to known regulatory RNAs such as $\mathrm{Y}$ RNAs, vault RNAs and snoRNAs. One of the shyRNAs derive from the antisense strand of the Dicerl gene, termed Shad1 (short antisense to Dicer $\underline{1}$ ), and found to regulate the proliferation of PC-3 cells. Furthermore, Shad1 RNA colocalizes with $\mathrm{YB}-1$ in P-bodies and stress granules upon oxidative stress of PC-3 cells. Therefore, shyRNAs have the capacity to impact many fundamental biochemical pathways through the interaction with the global regulator, YB-1.

\section{RESULTS}

\section{YB-1 associates with a variety of noncoding RNAs}

PC-3 cell lysates were subjected to immunoprecipitation with a YB-1 antibody under conditions expected to stabilize RNAprotein complexes. As shown in results of the Bioanalyzer analysis of RNA species enriched in YB-1 immunoprecipitates relative to nonimmune IgG complexes, the YB-1 RNA fraction is highly enriched in small RNAs with distinct and prominent peaks at 16, 22, and $28 \mathrm{nt}$ (Fig. 1A). The profile of RNA species associated with another protein containing two RNA binding domains (i.e., hnRNP A/B) does not match that identified in YB-1 immunoprecipitates indicating that not all RNA binding proteins bind small RNAs. The YB-1-associated small RNAs ( $\sim 10-50 \mathrm{nt})$ were therefore size-fractionated and sequenced using the Illumina small RNAsequencing protocol. A total of 185,105 distinct genomic loci $(14,042,214$ reads) were cloned with 156,006 locations
$(14,012,548$ reads) representing >1 RPKM. One smyRNA-sequenced maps to a novel gene locus that is antisense to the first exon of the Dicer transcript, KI AA0928. Northern blot analysis validates that the Shad1 small RNA was indeed present in YB-1 immunoprecipitated samples as compared with input and IgG controls (Fig. 1B). Northern blotting also validated the presence of another highly sequenced smyRNAs selectively enriched in YB-1 immunoprecipitates (i.e., Saunc45b) (Fig. 1B). RNA EMSAs using purified GST-tagged YB-1 protein demonstrate a direct interaction between YB-1 and the DIG-labeled small Shad1 RNA, suggesting that the association between YB-1 and Shad1 in immunoprecipitates may be indicative of an interaction that occurs in vivo (Fig. 1C). Addition of excess unlabeled Shad1 eliminates the detectable shift due to the binding of the tagged protein. YB-1 is known to bind directly to the RNA transcribed from the fourth exon on the CD44 gene both in vivo and in vitro (Stickeler et al. 2001). To test the specificity of RNA binding, CD $44 v 4$ was used as a positive control in the EMSA not only to test the specificity with the addition of excess unlabeled probes, but also with increasing concentrations of either labeled probe or tagged YB-1 protein (Supplemental Fig. S1).

In addition to validating the presence of sequenced smyRNAs, Northern blot analysis also identified additional higher molecular weight bands RNAs containing the same small RNA sequence, which could be precursors of Shad1 and Saunc45B RNAs (Fig. 1B). YB-1-associated RNAs were therefore size fractionated from $\sim 10$ to $250 \mathrm{nt}$ and pairedend sequenced to examine the different size populations. A total of 403,455 distinct genomic loci (32,916,224 reads) were mapped to the genome and of those, 281,686 loci $(32,720,233$ reads) represent locations $>1$ RPKM. The size distribution of each unique paired-end read shows two distinct populations of RNAs with an enrichment of RNAs in the range of $16-48 \mathrm{nt}$, similar to the distribution from the Bioanalyzer assays (Fig. 1D, red). To normalize for any artifacts related to ligation, amplification and nonspecific binding of abundant RNAs, the same size fraction was also sequenced from the PC-3 input samples. A total of 412,690 distinct genomic loci $(67,175,643$ reads) were mapped with 115,496 loci $(66,688,207$ reads $)$ representing locations $>1$ RPKM. Only genomic locations (247,547 clusters; $22,938,551$ reads) where there was at least a twofold enrichment over the input library and the locations with $>1$ RPKM were considered resulting in a conservative group of YB-1-associated RNAs. The size distribution of these YB-1-associated RNAs remains very similar to the nonnormalized data set (Fig. 1D, blue). Examination of the 188,061 smyRNA locations $(7,594,709$ reads) revealed that a small percentage of reads correspond to annotated tRNAs (6.5\%) and snoRNAs (3\%) (Fig. 1E). Because smyRNAs sequenced from the input samples were removed from the YB-1 IP samples, the reads attributed to tRNAs and snoRNAs are not due to nonspecific associations or ligation bias due to the sequencing technologies. The high percentage of snoRNAs sequenced suggests an enrichment of 
A

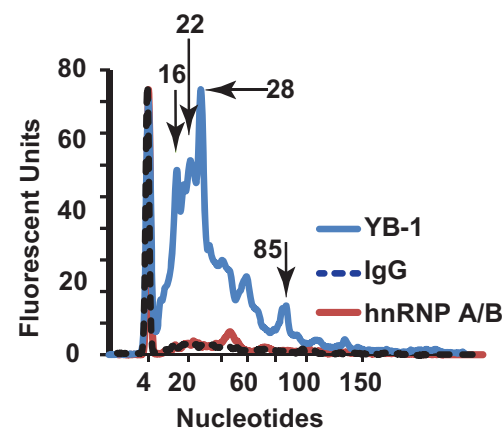

C

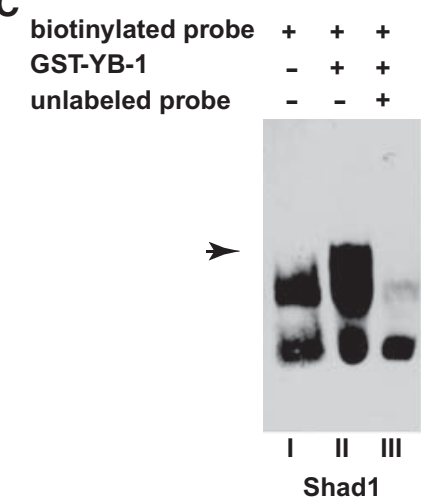

E

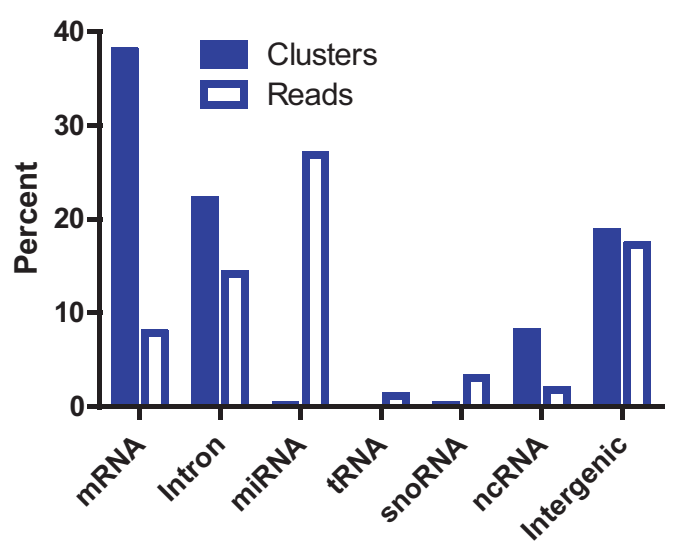

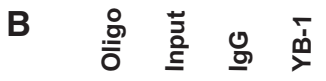

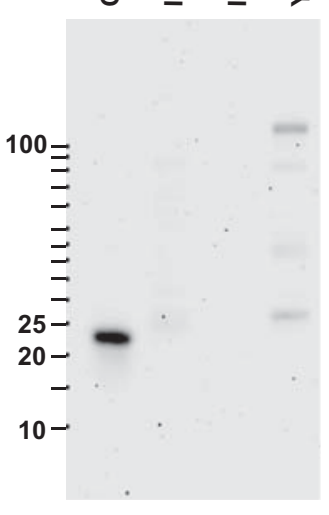

Shad1

D

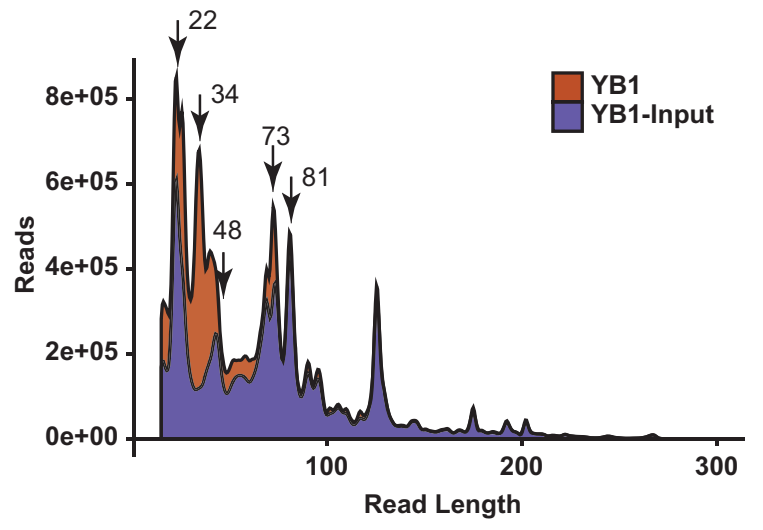

FIGURE 1. Characteristics of YB-1-associated small RNAs. (A) Length distribution of small RNAs immunoprecipitated with YB-1, hnRNP A/B (control), and rabbit IgG (control), based on Agilent Bioanalyzer (marker peak at $4 \mathrm{nt}$ ). (B) Northern blot validation of two abundant small RNAs, Shad1 and Saunc45b. A more abundant 100 -nt long Shad1 isoform was also detected. $(C)$ RNA EMSA using purified GST-YB-1 protein shows interaction with Shad1. (Lane I) DIG-labeled probe in the absence of YB-1. (Lane II) Labeled probed in the presence of YB-1. (Lane III) Labeled probe, YB-1 and an excess (20x) of unlabeled RNA probes as competitor. All reactions use unlabeled tRNA as a nonspecific competitor. $(D)$ Size distribution of paired-end reads. The red distribution shows all read lengths from the YB-1 RNA immunoprecipitation. The blue distribution shows all read lengths from the YB-1 RNA immunoprecipitation twofold enriched over PC-3 input RNAs. (E) Analysis of distinct YB-1-associated small RNA sequences after removal of input RNAs.

sdRNAs associated with YB-1 (Taft et al. 2009). On the other hand, miRNA reads accounted for $27 \%$ of total smyRNAs. The enrichment of known small noncoding RNAs associated with YB-1 suggests a functional role for YB-1 in the small RNA pathway.
A second population of RNAs, $\sim 63-86 \mathrm{nt}$ in length, emerged upon sequencing a larger size distribution of RNAs associated with YB-1 (Fig. 1E). In total, we sequenced 67,132 distinct shyRNA loci $(6,342,725$ reads). Only a low percentage of all reads (7.7\%) map to tRNA locations (Fig. 
$2 \mathrm{~A}$ ). In contrast, $52.5 \%$ of the reads within this shyRNA fraction still map to snoRNAs. Recurrent enrichment of snoRNAs in both the shy and small RNA fractions, over similarly sized RNAs, adds support to the notion that YB-1 preferentially associates with both snoRNAs and their processed, smaller sdRNAs. To analyze whether shyRNAs have polyadenylated isoforms, similar to that of exosome-dependent pro- moter associated RNAs (Preker et al. 2008), we identified the polyadenylation sites across the genome using Direct RNA sequencing (DRS) (Ozsolak et al. 2010) in PC-3 cells and found that the majority ( $83 \%$ ) of shyRNA locations do not overlap with polyadenylation sites.

The presence of longer RNA sequences in Northern blot analysis of YB-1-associated RNAs, the preferential
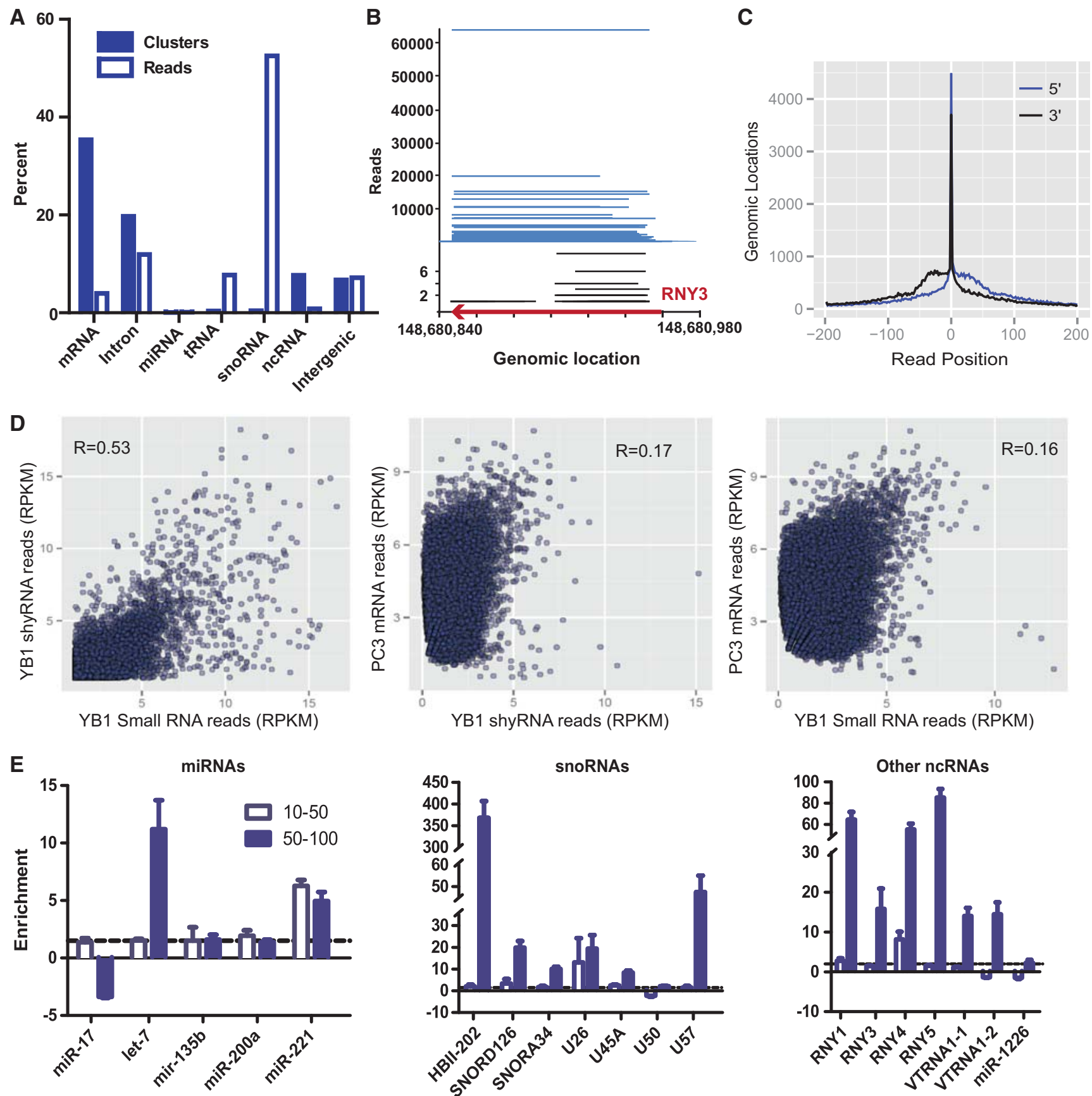

FIGURE 2. Characteristics of YB-1-associated short RNAs. (A) Analysis of distinct YB-1-associated short RNAs (shyRNAs) after removal of input RNAs. (B) The RNY3 RNA is matched to YB-1-associated shyRNAs (blue) and low abundance small RNAs (black) that preferentially derive from either the $5^{\prime}$ or $3^{\prime}$ ends of RNY3. The $y$-axis represents the number of reads while the $x$-axis shows the genomic location of the reads. The most abundant read is nearly identical to RNY3. (C) Small RNAs preferentially match to the $5^{\prime}$ and $3^{\prime}$ ends of shyRNAs. (D) Correlation between shyRNAs, small RNAs, and mRNAs in PC-3 cells. (E) qPCR validation of different classes of small and shyRNAs. 
association of snoRNAs and their derivatives with YB-1, and the evidence that long RNAs ( $>200 \mathrm{nt})$ are processed into short RNAs $(<200 \mathrm{nt})$ raised the possibility that shyRNAs are processed into smaller RNAs (Kapranov et al. 2007). Indeed, among the 247,547 distinct shyRNA genomic locations, $\sim 62 \%$ generate YB- 1 -associated small RNAs that considerably overlap $(\geq 80 \%)$ with their cognate short RNA sequences. This property is not seen with the small and short RNA fractions in the input controls with only 1340 of 84,981 locations (1.6\%) reflective of a precursor/product relationship. An inspection of smyRNAs generated from longer shyRNAs, such as the case for $R N Y 3$, reveals a general preference for shyRNAs to generate small RNAs from either the $5^{\prime}$ or $3^{\prime}$ termini (Fig. 2B). The most abundant RNY3 small RNA is located toward the $5^{\prime}$ end of the short RNA. An additional small RNA that is seemingly less abundant is located close to the $3^{\prime}$ end. The lack of small RNAs deriving from other regions of RNY3 is reminiscent of other small RNAs that manifest terminal bias, such as tRNA-derived fragments (Lee et al. 2009) and snoRNAs-derived RNAs (Taft et al. 2009; Lin et al. 2012). A more comprehensive analysis of the locations of the small RNAs within shyRNAs indicates that shyRNAs are preferentially processed from their $5^{\prime}$ or $3^{\prime}$ ends (Fig. 2C). The correlation between the abundance of shyRNAs and their small RNAs is also high $(R=0.53)$ (Fig. 2D). To investigate whether mRNA expression correlates to their corresponding shyRNAs and the small RNAs, we quantified transcript levels of exons in PC-3 using Illumina RNA-seq data. Negligible correlation was seen between mRNAs and the shyRNAs, as well as mRNAs and the small RNAs $(R=0.17-0.16)$ (Fig. $2 \mathrm{D})$. These results suggest that shyRNA sequences generally serve as precursors to YB-1-associated small RNAs. Quantitative RT-PCR (qPCR) validation was performed on sizefractionated YB-1-associated RNAs to examine the observed association of 26 RNAs (Fig. 2E). Several well characterized small/short noncoding RNAs such as mirtrons and vault RNAs are also present among the YB-1-associated RNA reads. For instance, the recently discovered MALAT1-associated small ( $\sim 60 \mathrm{nt})$ cytoplasmic RNA, mascRNA, generates a novel small RNA that is processed precisely from the $5^{\prime}$ end of the annotated mascRNA. Similarly, 77\% (10/13) of a high-confidence set of cytoplasmic human mirtrons were detected (Sibley et al. 2011). Three of the four cytoplasmic vault RNAs also overlap with both shyRNAs and their terminal smyRNAs.

While the correlation between the shyRNAs and their equivalent smyRNA is high, there still exists the possibility that these YB-1-associated RNAs are simply a byproduct of some RNA degradation process within the cell. A recent study examined small noncoding RNAs (18-30 and 30-100 nt) and the effects of the processing of these RNAs in the absence of the endonuclease RRP40 or the exonucleases XRN1 and XRN2 (Valen et al. 2011). RNA categories identified in these analyses as either RRP40, XRN1, and XRN2-dependent or independent were then overlapped with the YB-1-associated
RNAs in order to assess the potential contribution of these endo-/exonucleases to the processing these RNAs with the caveat that this comparison was being made with two distinct human cell lines. Nonetheless, only $3 \%$ of the small and $0.5 \%-0.7 \%$ of the shyRNAs could be considered dependent on RRP 40 or XRN1/2 for processing. Similarly, $3 \%$ of the small and $0.4 \%-0.5 \%$ of the shyRNAs represents known degradation products of RRP40 and XRN1/2. Therefore, the vast majority of shyRNAs are unlikely to be generated by degradation by the major RNA processing endonuclease and exonucleases found in human cells.

\section{Shad1 influences expression of prognostic markers of metastasis}

Surprisingly, while initial sequencing experiments recovered Shad1 small RNAs, it was not as abundantly present in the Illumina reads when the larger fraction was sequenced. This could result from either a $5^{\prime}$ or $3^{\prime}$ end modification in Shad1 RNA that would reduce the efficiency of adaptor ligation used to prep samples for Illumina sequencing. To test for $5^{\prime}$ terminal RNA modifications, YB-1 immunoprecipitated RNA was treated with a $5^{\prime}$ monophosphate-dependent exonuclease. For both the 25 and 100 nt forms of Shad1, the exonuclease treatment results in Shad1 degradation, ruling out the presence of a $5^{\prime}$ modification (Fig. 3A). To test for the presence of $3^{\prime}$ modifications, YB-1 immunoprecipitated RNA was subjected to periodate oxidation followed by polyadenylation and qPCR. qPCR of Shad1 with and without periodate oxidation reveals little change in amplification efficiency suggesting that a $3^{\prime}$ modification may exist (Fig. 3B). A synthetic miR-135 oligo containing a $2^{\prime}-\mathrm{O}$-methylation at the $3^{\prime}$ end yields similar results, while the novel small RNA derived from the human Y RNA, RNY3, prominently sequenced in association with YB-1, manifests a clear difference. Therefore, this modification is likely responsible for limiting ligation of the $3^{\prime}$ sequencing adapter necessary for Illumina sequencing. Although the $3^{\prime}$ modification did limit the number of reads generated from Shad1, we inferred the genomic location of Shad 1 through the combination of single-end and paired-end sequencing of YB-1-associated RNAs (Fig. 3C).

Although we show that Shad1 is directly bound by YB-1, we sought to examine if levels of Shad1 correlate with YB-1 expression. In order to differentiate between the Shad1 shyRNA and the Shadl smyRNA, oligos were synthesized for complementary to the common short/small region (Shad1) or specifically to the short region (Shad1 $[-50]$ ). In a normal prostate epithelial cell line, RWPE-1, YB-1 is down-regulated compared with PC-3; in the same cell line, Shad1 is also significantly down-regulated (Fig. 3D). When YB-1 expression is knocked down with a lentiviral shRNA, Shad1 expression likewise decreases (Fig. 3E). Finally, when a CMV-YB-1 is stably transfected into the RWPE-1 cell line to increase the expression of YB-1, Shad1 expression increases with that of YB-1 (Fig. 3F). Under the same conditions, 

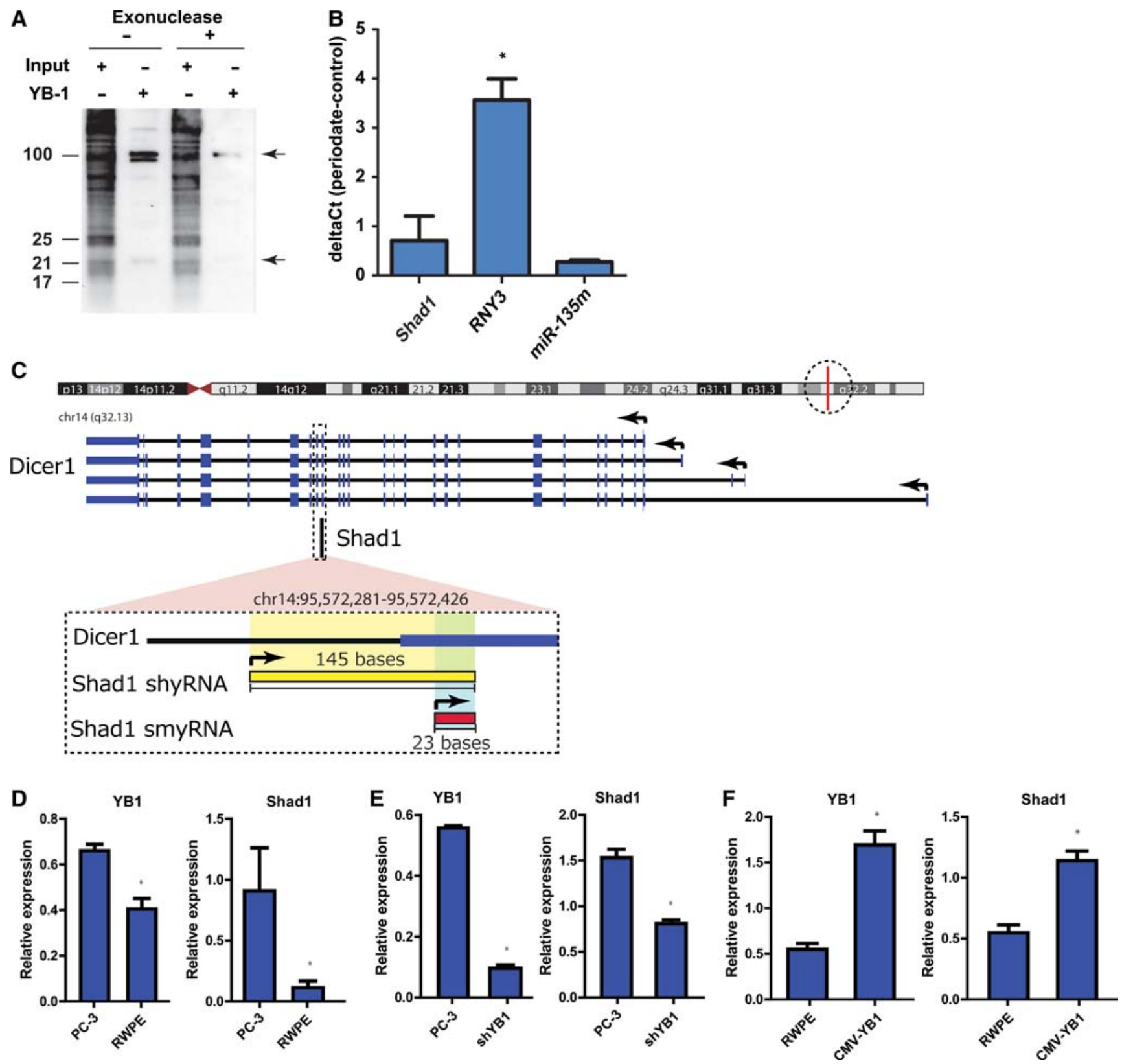

FIGURE 3. Shad1 modification and correlation of expression with YB-1. (A) The Shad1 RNAs possess a $5^{\prime}$-phosphate as indicated by a $5^{\prime}$-phosphatedependent exonuclease reaction. (B) Periodate oxidation followed by polyadenylation and qPCR reveals $3^{\prime}$ modifications in YB-1-associated RNAs and the positive control, miR-135m, a synthetic oligo with a $3^{\prime}$ end $2^{\prime}$-O-methyl modification. $(C)$ Genomic location of Shad1 shyRNA and smyRNA as determined by sequencing of YB-1-associated RNAs. $(D)$ In a normal prostate epithelial cell line (RWPE), YB-1 expression is less than that of the prostate cancer cell line (PC-3). Shad1 level is also down-regulated in RWPE compared with PC-3. (E) Upon lentiviral infection with shRNA for YB-1, Shad1 levels also decrease. (F) Upon overexpression of YB-1, Shad1 levels are also increased. (*) $P$-values $<0.05 ; n=3$.

qPCR was performed using oligos specific to the Shad1 shyRNA only (Supplemental Fig. S2A-C). Similar to the Shad1 qPCR results, the expression of Shad1 shyRNA correlates with the expression of YB-1 in all cell lines. Examination of a gene not known to be regulated by YB-1 expression was also checked as a negative control, and there was no correlation of GusB expression with that of YB-1 or Shad1 (Supplemental Fig. S2D-F). These results in sum suggest that
Shad1 expression is tightly linked to that of its protein partner, YB-1.

In order to investigate whether Shad1 shyRNA has a functional role in PC-3 cells, we designed LNA oligos antisense for both the short/small Shad1 isoform (aShad1) and the specific short Shad1 isoform (aShad1 (-50)). Transfections of aShad1 LNAs result in increase in metabolic activity compared with the scrambled control LNA oligo (Fig. 4A). Cytotoxicity 
assays of the transfections showed no increased cell death in the transfection reactions as opposed to negative (control untreated) and positive (fully lysed) controls (Fig. 4B). Cell counts also showed no cell death with increased proliferation in the cells transfected with both LNA oligos that are complementary to Shad1 (Fig. 4C). Taken together, Shad1 functions in PC-3 cells to repress proliferation. Since Shad 1 is antisense to Dicer1, blocking Shad1 could remove its potential function as a regulator of Dicer1 expression. Shad1 inactivation was examined by qPCR between the scrambled (scr) control and the aShad1 LNA (Fig. 4D). When the aShad1 LNA was transfected, there is a statistically significant decrease in Shad1
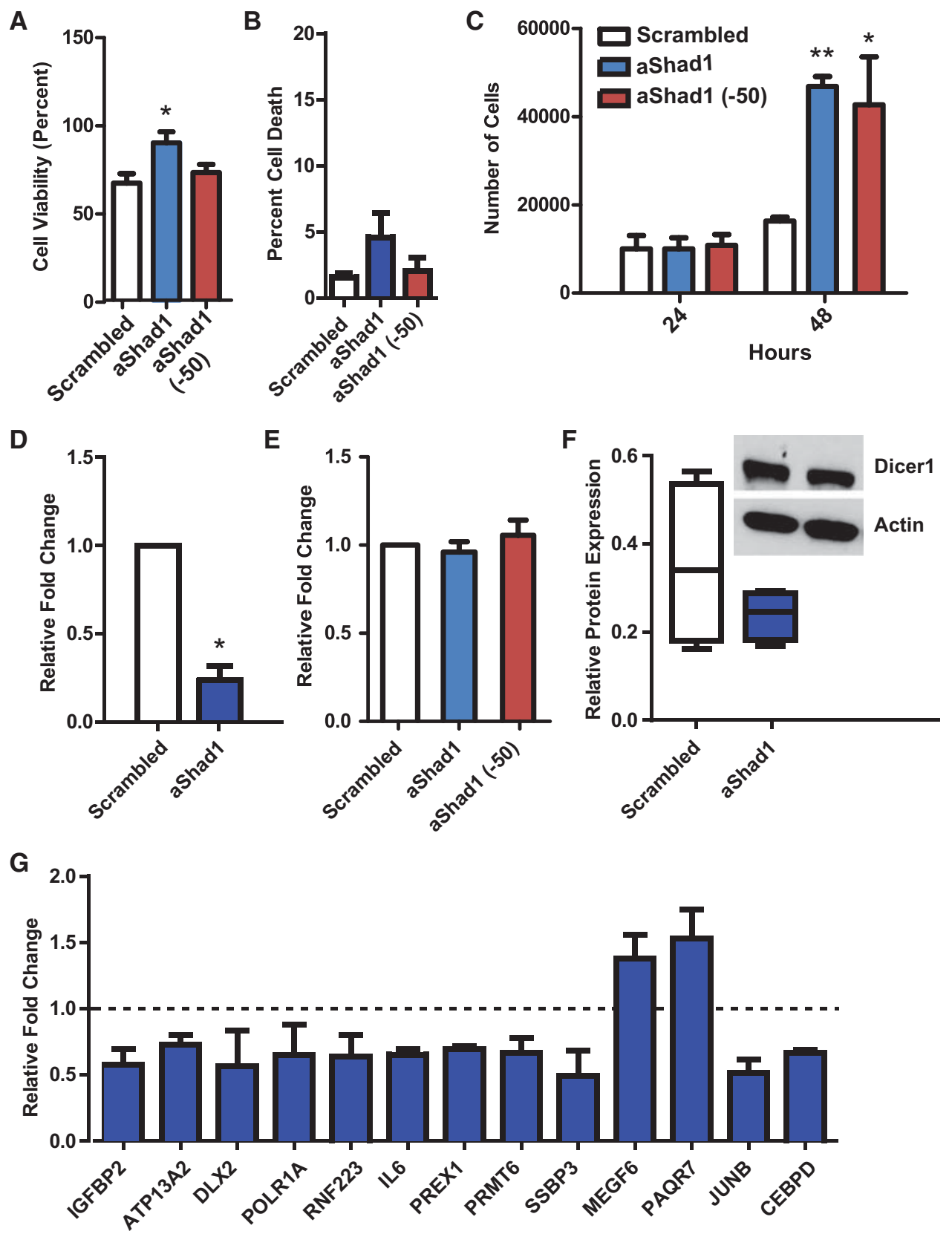

FIGURE 4. Characterization of probable Shad 1 function. (A) MTT assay of cells $48 \mathrm{~h}$ post-transfection. Percent cell viability is based on nontransfected cells plated at the same initial density. $\left.{ }^{*}\right) P$-value $<0.05 ; n=3$. (B) Cytotoxicity assay shows no significant cell death upon Shad 1 knockdown. (C) Cell counts of transfected cells at 24 and 48 h post-transfection. $\left.{ }^{*}\right) P$-value $<0.05$; ( $\left.{ }^{* *}\right) P$-value $<0.001 ; n=3$. $(D)$ Transfection with LNA antisense to Shad1 (aShad1) shows a decrease in Shad1 expression compared with scrambled control. $\left(^{*}\right) P$-value $<0.05 ; n=3$. (E) Shad 1 knockdown shows no difference in Dicer1 mRNA levels $(P$-value $=0.5002 ; n=3)$. $(F)$ Shad 1 knockdown shows no difference in Dicer1 protein levels $(P$-value $=0.2907 ; n=$ 4). Representative Western blot illustrates band intensities used for quantitation (inset). ( $G$ ) qPCR validation of genes differentially expressed upon Shadl knockdown. All genes are significantly differentially expressed with $P$-values $<0.05 ; n=3$. Dashed line represents no relative change; anything above is up-regulated and below is down-regulated. 
expression. Further examination by qPCR of Dicer1 expression showed no significant difference in Dicer1 mRNA is PC-3 cells (Fig. 4E); Western blot showed no significant difference in Dicer1 protein (Fig. 4F). Since there was no significant change in Dicer1 expression or protein levels, Shad1 may be having a unique role in $\mathrm{mRNA}$ regulation independent of Dicer1. DRS was performed on both the scr control and the aShad1 LNA knockdown cells to examine gene expression changes, and there were 115 genes differentially expressed between the two conditions. A few of the most differentially expressed genes, $D L X 2, I G F B P 2$, and $I L-6$, were reconfirmed by qPCR and are known markers of cancer progression and poor patient outcome (Fig. 4G). Because of the closely linked nature of Shad1 and YB-1, we examined the Shad1-dependent genes in reference to YB-1 expression. Of the 13 genes examined in the Shad1 LNA knockdown cells, 10 genes remained significantly differentially regulated in response to $\mathrm{YB}-1$ knockdown (Supplemental Fig. S3A). However, there were no consistent changes in gene expression when the genes were examined in normal prostate epithelial cells with or without YB-1 overexpression. Motif analysis of Shad1 regulated genes revealed a consensus motif shared between all disregulated genes, but this motif did not correspond to either the YB-1 binding site or Shad1 complementary sequence indicating that it is unlikely that YB-1 in conjunction with Shad1 binds directly to regulate the expression of these genes (Supplemental Fig. S3B). A TOMTOM scan of the Shad1 consensus motif revealed only 24 hits in 1329 total motifs in the vertebrate database (1.8\%) (Gupta et al. 2007). Additionally, a FIMO search found no statistically significant enrichment of the Shad1 consensus motif in the human nucleotide database indicating that there is no enrichment of this motif among genes that are not Shad1 regulated (Grant et al. 2011). These results reveal that Shad1 and YB1 expression is closely linked, and Shad 1 likely plays an indirect role in the expression of other prognostic markers of cancer metastasis. These results also indicate that YB-1 and Shad 1 expression alone is insufficient to disregulate genes associated with cancer metastasis in normal prostate epithelial cells.

\section{Shad1 is evolutionarily conserved and localizes to mammalian P-bodies/stress granules}

YB-1 is known to be highly conserved from bacteria to all vertebrate species examined and its subcellular localization can be influenced by cellular stress (Christov et al. 2006; Krude et al. 2009). For example, YB-1 associates with two distinct stress-responsive cellular structures, the mRNA degradation-related P-bodies ( $\mathrm{PB})$, and stress granules that are sites of mRNA processing (Kedersha and Anderson 2007). In six cell lines comprising human (PC-3, HeLa, HEK293, MCF7), mouse (P19), and monkey (COS7), YB-1 consistently localizes to the cytoplasm of the cells under normal growth conditions (Fig. 5; Supplemental Figs. S4-S8). While Shad1 is also primarily localized within the cytoplasm, it is detectable in the nucleus of HeLa cells. When cells are exposed to stress conditions, YB-1 and Shad1 form punctate structures in the cytoplasm in all cell lines tested. For example, upon heat shock for $45 \mathrm{~min}, 30 \%$ of YB-1/Shad 1 punctate structures colocalize with GW182, a marker for PBs but not SGs, which represents $40 \%$ of labeled PBs (Fig. 5A). Upon a 2 h heat shock, $50 \%$ of YB-1/Shad1 structures colocalize with PBs, representing 70\% of PBs. When cells are treated with arsenite, an oxidative stress agent, $60 \%$ colocalize to $90 \%$ of PBs. Under the same arsenite exposure conditions, $80 \%$ of YB-1/Shad 1 colocalizes in $70 \%$ of eIF3, a marker for SGs but not PBs (Fig. 5B). The colocalization of eIF3 with YB-1 and Shad1 is also visible upon heat shock (40\% and $60 \%$ colocalization, respectively). In some instances, a minor fraction of Shad 1 and YB-1 are also detected in the nucleus (Supplemental Fig. S4). To compare the localization differences between the Shad1 shyRNA and Shad1 smyRNA, we used another probe that targets the immediate upstream location of the Shad1-derived small RNA. Although the Shad1 shyRNA showed more punctate staining even under nonstress conditions in PC-3 cells, colocalization patterns with YB-1 and PBs or SGs remained the same when cells were subjected to heat shock and arsenite stress (Supplemental Fig. S9). To further confirm that the observed localization patterns are truly attributed to YB-1, we used a FLAG-tagged YB-1 in HeLa S3 cells to reconfirm the localization of Shad1 with YB-1 under stress conditions (Supplemental Fig. S10). To verify that the GW182 cytoplasmic structures were actually P-bodies, we also used Dcpla as another maker of PBs (Supplemental Fig. S11). Finally, we tested whether Shad1 levels change after arsenite treatment. Northern blot analysis revealed that stress induced recruitment of Shad1 to PBs/SGs does not reflect an elevated level of Shad1 (Supplemental Fig. S12). Taken together, Shad1 is not only associated with YB-1 across a variety of cell types, but colocalizes to stress-responsive structures specifically with YB-1.

\section{DISCUSSION}

The YB-1 protein utilizes its DNA and RNA binding activity to influence various aspects of nucleic acid metabolism including DNA replication, transcription, mRNA splicing, and export. We have identified a unique regulatory mechanism for YB-1 that is mediated by a novel class of short RNAs termed shyRNAs and their processed small RNAs (smyRNAs) that specifically associate with YB-1, perhaps as shown in one case by a direct interaction. It seems likely that only a minor proportion of shyRNAs represent degradation products of longer noncoding RNAs or mRNAs since the overlap between shyRNAs and RNA-seq data from endo- and exonuclease knockdown cells are low. While the biosynthesis of these RNAs is unknown, the number of functional noncoding RNAs associated with YB-1 (i.e., RNY3, MALAT-1) suggests that YB-1 is important in the small RNA pathway. Previous studies have shown that YB-1 
A
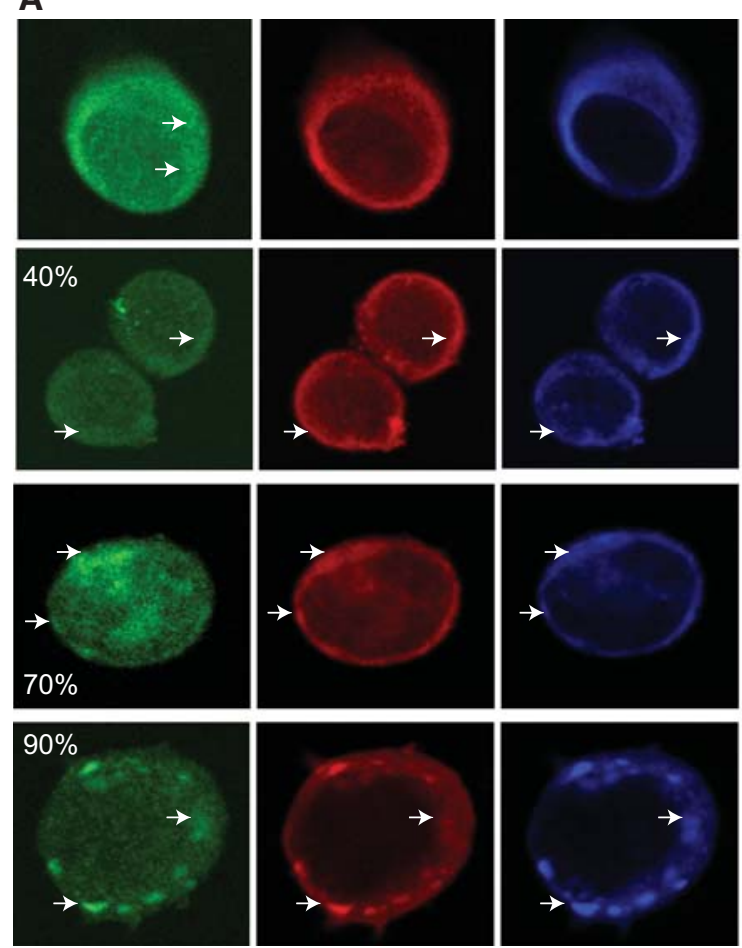

GW182

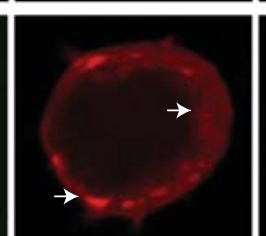

Shad1

B
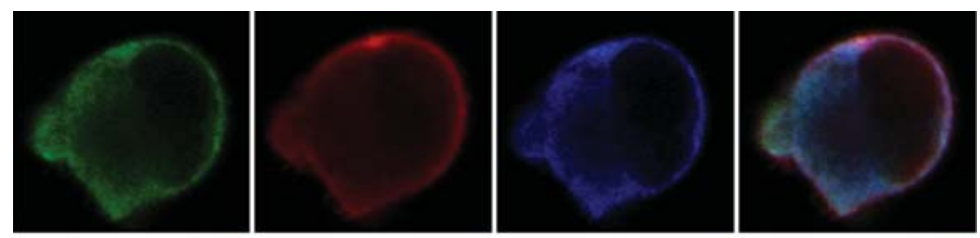

Control
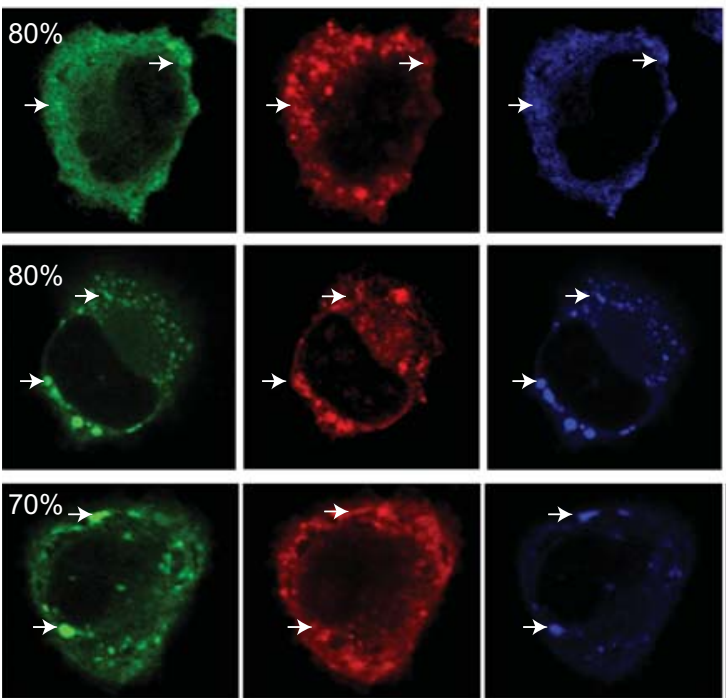

elF3

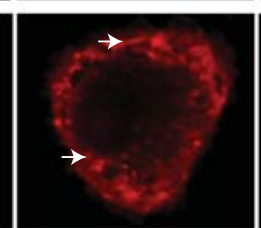

Shad1
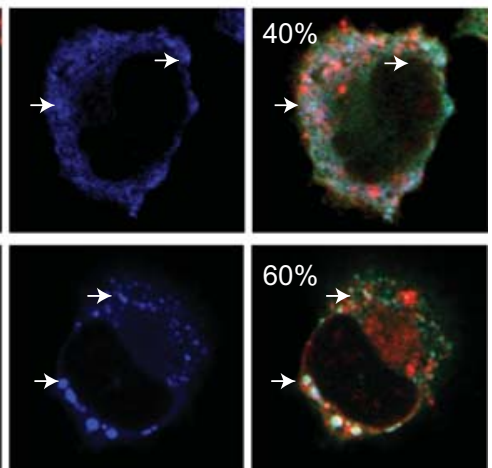

Heat Shock 45 minutes

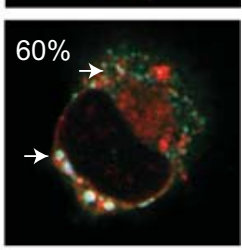

Heat Shock

2 hours

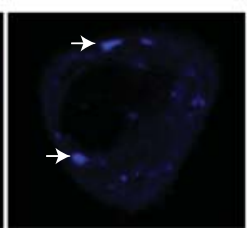

YB-1

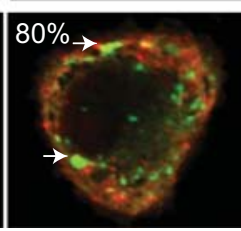

Merge

FIGURE 5. YB-1 colocalizes with Shad1 to cytoplasmic bodies in PC-3 cells. (A) Upon heat shock or oxidative stress (arsenite), Shad1 localizes with YB-1 to P-bodies (GW182). (B) Under the same conditions, some of the Shad1 localizes with YB-1 to stress granules (eIF3). Percent colocalization of Shad1/YB-1 to cytoplasmic bodies are indicated on merged panels and the percent of cytoplasmic bodies with Shad1/YB-1 are indicated in the PB/SG panels.

associates with AGO proteins so some of these shy- and smy-RNAs may associate with both YB-1 and AGO in a complex.

To examine the potential biological relevance of the unique YB-1-associated RNAs that we identified, functional assays were performed with validated shyRNAs such as one derived from the antisense strand of Dicer that we designated as Shad1. The increased proliferation of PC-3 cells upon Shad1 ablation seems contradictory since YB-1 overexpression reportedly plays a role in tumor progression and outcome. However, we show that blocking Shad1 decreases the expression of many other genes know to predict cancer progression and metastasis. The transcription factor DLX2 has been shown to inhibit apoptosis induced by TGF $\beta$ and the expression of DLX 2 correlates with tumor progression and metastasis in melanoma, glioma, lung, and prostate cancers (Yilmaz et al. 2011). Another gene whose overexpression correlates with tumor progression and is down-regulated in the absence of Shad1 is $I G F B P 2$. Previous studies have shown that IGFBP2 is overexpressed in glioma, prostate, and breast cancers (Kanety et al. 1993; Busund et al. 2005; Lin et al. 2009). In prostate cancer, serum levels of IGFBP2 can be measured and levels increase as the cancer progresses (Shariat et al. 2002; Bensalah et al. 2008). IL-6, a cytokine that can be both pro- and antiinflammatory, plays an important role in the metastasis of prostate cancer (Shariat et al. 2002). Endothelial cells have been shown to excrete IL-6 resulting in a decrease in androgen receptor activity leading to increased invasion of the epithelial cells (Wang et al. 2013). In HER2 positive breast cancer, IL-6 expression is increased as well (Hartman et al. 2011). However, YB-1 overexpression in breast cancer cells actually decreases cell growth rather than promoting proliferation ( $\mathrm{Ga}$ rand et al. 2011). Since one property of YB-1 overexpression is cisplatin resistance and cisplatin functions by forming DNA crosslinks during replication, the drop in proliferation could render treatment less efficacious. Instead, the overexpression of YB-1 in decreasing proliferation could be promoting enhanced 
migration and epithelial-mesenchymal transition (EMT) (Evdokimova et al. 2009a,b). Shad1 can be found not only in different mammalian cell lines we examined (mouse and monkey), but it is also expressed in normal cell lines at levels corresponding to YB-1 expression. The fact that Shad1 is antisense to Dicer 1 means that any blockade of Shad1 requires a sequence that would not affect Dicer1 expression, making it a potential target that would specifically inhibit a handful of genes important to tumor progression instead of inhibiting a multifunctional protein like YB-1. Taken together with the observation that shyRNAs include many known regulatory short RNAs such as Y RNAs, pre-miRNAs, and snoRNAs, these observations support the notion that shyRNAs represent a group of RNAs that share a common pathway but have evolutionarily acquired diverse cellular roles.

\section{MATERIALS AND METHODS}

\section{Cell culture and proliferation}

PC-3, HeLa, HEK293, MCF-7, and COS7 cells were maintained in RPMI1640 supplemented with 10\% fetal bovine serum and $1 \%$ penicillin/streptomycin. P19 cells were maintained in DMEM supplemented with $10 \%$ FBS and $1 \%$ penicillin/streptomycin. RWPE1 cells were maintained in Keratinocyte-serum free media supplemented with bovine pituitary extract and epidermal growth factor (EGF). Cell proliferation was determined with the Vybrant MTT cell proliferation assay (Invitrogen) and trypan blue cell count at $48 \mathrm{~h}$ post-transfection.

\section{RNA immunoprecipitation}

Cells were grown to $70 \%$ confluence in $15 \mathrm{~cm}$ plates and lysed with RNA immunoprecipitation lysis buffer $(20 \mathrm{mM}$ Tris- $\mathrm{HCl} \mathrm{pH} 7.5$, $150 \mathrm{mM} \mathrm{NaCl}, 0.25 \% \mathrm{NP}-40,1.5 \mathrm{mM} \mathrm{MgCl}$, protease inhibitors, PMSF, and RNaseOUT). Protein A/G agarose beads (Santa Cruz) were prewashed with RNA wash buffer $(20 \mathrm{mM}$ Tris- $\mathrm{HCl} \mathrm{pH} 7.5$, $150 \mathrm{mM} \mathrm{NaCl}, 0.5 \% \mathrm{NP}-40,1.5 \mathrm{mM} \mathrm{MgCl}_{2}$ ). For antibody-immobilized beads, $2 \mu \mathrm{g}$ of YB-1 (Abcam), normal rabbit IgG (Santa Cruz), or hnRNP A/B (Santa Cruz) antibody was added to the bead/wash buffer solution and incubated at $4^{\circ} \mathrm{C}$ for $90 \mathrm{~min}$. Cell lysates were precleared with washed agarose beads for $60 \mathrm{~min}$. Equal volumes of supernatant were either saved as input sample or applied to the antibody-immobilized beads and incubated at $4^{\circ} \mathrm{C}$ for 3 h. The antibody-immobilized beads-RNP complexes were washed three times in wash buffer and treated with proteinase $\mathrm{K}$ at $45^{\circ} \mathrm{C}$ for $30 \mathrm{~min}$. After protein digestion, RNA was isolated using TRIzol (Invitrogen) and chloroform (Sigma).

\section{RNA sequencing}

RNA obtained from the immunoprecipitation experiments were size fractionated on a polyacrylamide-urea gel (National Diagnostics) and gel slices were crushed and resuspended in $0.4 \mathrm{M} \mathrm{NaCl}$, frozen, and incubated at $42^{\circ} \mathrm{C}$ overnight. The acrylamide was removed by passing the suspension through Nanosep 100K filters (Pall Corp.) and RNA was precipitated. $5^{\prime}$ phosphate-dependent cDNA libraries were prepared using the manufacturer TruSeq small RNA-sequenc- ing protocol. Small RNA $3^{\prime}$ and $5^{\prime}$ adapters were ligated to the RNAs using T4 RNA Ligase 2 and cDNA synthesis was performed using the RNA RT primer (RTP) and SuperScript II reverse transcriptase. PCR amplification was performed with RNA PCR primer (RP1) and primer index (RPIX) and Phusion DNA polymerase. The cDNA library was then size fractionated on a 6\%-12\% PAGE gel and the library recovered for sequencing. The small RNA was single-end sequenced while the $\sim 10-250$ nt library was paired-end sequenced (Tufts core facility).

\section{Genomic analysis}

All sequence mapping and filtering were performed in house. Illumina FASTQ files were processed to retrieve sequences with Phred quality score to ensure a base call accuracy of 99\%. The 3\% adapter sequences and reads shorter than 15 nucleotides were removed using cutadapt. The filtered RNA reads were mapped to the human genome (GRCh37) using Bowtie. The mapped locations were then further filtered to only retain those reads that matched to a single unique location in the genome and were $>1$ RPKM. Neighboring (distance $<10 \mathrm{nt}$ ) reads from identical strands were considered as part of a single genomic cluster for annotations using UCSC Genome Browser and Bioconductor (Gentleman et al. 2004; Karolchik et al. 2009). For the paired-end sequencing reads, the libraries were normalized to the sequenced input RNA. Input RNAs that were greater than twofold enriched over YB-1 RNAs was considered to be the control RNA sequences; YB-1 RNAs that were greater than twofold enriched over input RNAs was considered to be the YB-1-associated RNA sequences.

\section{Statistical analysis}

Publicly available (embargo free) ChIP-seq data (ENCODE) of histone modifications ( 72 cell lines, 682 samples) and transcription factors ( 88 cell lines, 218 transcription factors, 1284 samples) from the UCSC genome browser portal were used to establish the preference of various genomic features to shyRNA locations. As a control group, the input RNA locations with at least twofold enrichment over YB-1 and >1 RPKM (96,335 locations) were defined. An equivalent number based on RPKM of YB-1-associated RNAs were selected. Bootstrapping analysis for YB-1 to histone modification/TF binding site enrichment was performed by randomly sampling (with replacement, $n=96,335$ ) the described sets of both YB-1 and control samples to yield 10 different data sets for each sample (YB-1 or control). The distances to the closest histone modification or TF binding sites for each $5^{\prime}$ end of the YB-1-associated RNAs or its equivalent control $5^{\prime}$ locations were calculated and binned (size $=200 \mathrm{nt}$ ). $P$-values were computed using the two tailed $t$-test based on the probability distribution of the YB- 1 and control bootstrapped data sets at position $0( \pm 100 \mathrm{nt})$.

\section{RNA electromobility shift assay}

GST-tagged YB-1 protein was constructed by subcloning the CDS of YB-1 into the vector pGEX-6P1. E. coli Rosetta was transformed and expression was induced at $18^{\circ} \mathrm{C}$ over night. Cells were lysed by sonication and protein was purified with Glutathione Sepharose 4B (GE Healthcare). Elution was done with Glutathione peptide, followed by dialysis over night against PBS. To generate synthetic RNAs for 
binding assays, DNA oligos were designed with a $\mathrm{T} 7$ promoter (underlined) AACCAAT CTCAACCAGCCACTGCCCTATAGTGAGT CGTATTA (Shad1) and TCCTTGTGGTTGT CTGAAGTAGCACTTCCGGATTTGAATGG CTTGGGTTCCA CTGGGTCCAGTCCTGG TTCCTATAGTGAGTCGTATTA (CD44v4). T7 in vitro transcription was performed using the T7 RNA polymerase (NEB) and the RNA was purified with phenol/chloroform extraction and ethanol precipitation. Synthesized RNAs were then $3^{\prime}$-biotin labeled (Pierce) and RNA probes were purified with phenol/chloroform extraction and ethanol precipitation. The binding reaction was carried out in $20 \mu \mathrm{L}$ of RNA binding buffer (100 mM HEPES pH 7.9, $100 \mathrm{mM} \mathrm{KCl,} 10$ $\mathrm{mM} \mathrm{MgCl} 2,10 \mathrm{mM}$ DTT), 5\% glycerol, $2 \mu \mathrm{g}$ tRNA (nonspecific competitor RNA). Where indicated, a 20-fold excess of unlabeled RNA probe was added to the reaction as a control for specificity. The reactions were incubated at room temperature for an hour and resolved on a $4.5 \%$ native polyacrylamide gel in $0.5 \times$ TBE buffer. The samples were electrotransferred to positively charged nylon membranes and UV crosslinked at $120 \mathrm{~mJ} / \mathrm{cm}^{2}$. Chemiluminescent detection of the biotin-labeled RNA probes was performed per manufacturer's instructions (Pierce).

\section{Northern blots and qRT-PCR}

RNA was separated by electrophoresis on 15\% polyacrylamide-urea gels and electrotransferred to positively charged nylon membranes (Roche). Northern blots were performed using our previously described protocol utilizing LNA probes, EDC crosslinking and DIG-labeled probes (Kim et al. 2010). EDC crosslinking was performed at $60^{\circ} \mathrm{C}$ for $1-2 \mathrm{~h}$ to facilitate adequate RNA-membrane crosslinking. LNA or DNA oligonucleotide probes were $3^{\prime}$-end labeled with digoxigenin (DIG) using an End Tailing Kit (Roche). Probe sequences used for detection are ACAATCT CAACCAGCCACT (Shad1), AATTGAGĀT AACTCACTACCTTCGGA CCAGCC (RNY1), TAGTCAAGTGAAGCAGTGGGAGTGGAGA (RNY3), and CCTCCGCTGAC TAATATG CTTAAATTCAGCGGGTCGCCACGTCTGA TCTGAGGTCGCG (Saunc45B) with LNA bases underlined. RNA-probe hybridizations were carried out overnight in Ultrahyb buffer (Ambion) at $42^{\circ} \mathrm{C}$.

RNA obtained from the immunoprecipitation experiments were size fractionated and gel purified. The NCode VILO cDNA synthesis and qRT-PCR kit was used to
TABLE 1. qRT-PCR primers for small RNA and shyRNA validation, and LNA oligos

\begin{tabular}{|c|c|c|}
\hline RNA & Forward primer & Reverse primer \\
\hline \multicolumn{3}{|l|}{ miRNAs } \\
\hline miR-17 & ACTGCAGTGAAGGCACTTGT & \\
\hline let-7g & $\begin{array}{l}\text { TGAGGTAGTAGTTTGTACAGTT } \\
\text { TGAGG }\end{array}$ & \\
\hline miR-135b & TGGCTTTTCATTCCTATGTGA & \\
\hline miR-200a & TAACACTGTCTGGTAACGATGT & \\
\hline miR-221 & AGCTACATTGTCTGCTGGGTTTC & \\
\hline \multicolumn{3}{|l|}{ Y RNAs } \\
\hline RNY1 & GGCTGGTCCGAAGGTAGTG & \\
\hline RNY3 & CTTCACTTGACTAGCСTTTTGC & \\
\hline RNY4 & СССССАСТGСТАААТTТGАСТ & \\
\hline RNY5 & GTTGGTCCGAGTGTTGTGG & \\
\hline \multicolumn{3}{|l|}{ snoRNAs } \\
\hline U45Af & TCAATGATGTGTTGGCATGT & \\
\hline U57f & TGATGAACTGTCTGAGССТGA & \\
\hline U26f & CGGGGATGATTTTACGAACT & \\
\hline U50 & TGATCTTATCCCGAACCTGAA & \\
\hline HBII2O2 & GATGACATTCTCCGGAATCG & GGAAAAGGGTTCAAATGTGC \\
\hline \multicolumn{3}{|l|}{ Vault RNAs } \\
\hline VTRNA1-1 & AGCTCAGCGGTTACTTCGAC & CCCAGACAGGTTGCTTGTTT \\
\hline VTRNA1-2 & AGCGGTTACTTCGAGTACATTG & GTCTCGAACCACCCAGAGAG \\
\hline \multicolumn{3}{|l|}{$\begin{array}{l}\text { Mirtrons } \\
\text { miR-1228 }\end{array}$} \\
\hline \multicolumn{3}{|c|}{ LNA oligos (locked nucleotides underlined) } \\
\hline Shad1 & ACAATCTCAACCAGCCACT & \\
\hline Shad1 $(-50)$ & CACTAGACATGCAGAGGTTCAC & \\
\hline \multicolumn{3}{|l|}{ mRNA } \\
\hline YB-1 & TAAAGTGCTTGCTTTTTGCC & ATAAAAАССССАТGСТGСАТ \\
\hline Dicer1 & CAAGTGTCAGCTGTCAGAACTC & CAАTCCACCACAАTСТСАСАТG \\
\hline IGFBP2 & GACAATGGCGATGACCACTCA & GTTCCTGTTGGCAGGGAGT \\
\hline ATP13A2 & GTGGGCCTTGTCCTGGTC & GGGAGGCACTGGTCTAGCA \\
\hline DLX2 & TTCGGATAGTGAACGGGAAG & GGGATCTCACCACTTTTCCA \\
\hline POLR1A & CAACACGTATGGCATTGAGG & CTGTAGCGGGGAAGAGTTTG \\
\hline IL6 & TAGCCGCCCCACACAGACAG & GGCTGGCATTTGTGGTTGGG \\
\hline RNF223 & AGCAGCTCCATAGССТCGAT & AGCTCCTTGGGTGTCTTGAA \\
\hline PREX1 & TCTССТCGGAGСТСТGСТАC & TTTTTGGCCAGAATCTCCAC \\
\hline PRMT6 & GGGAAGAACACGGATGAAAA & CACCTAGGGAGGGGGAATTA \\
\hline SSBP3 & ATGAGACCACCACCCAACTC & ACTGGGCATAATGGGTGTTC \\
\hline MEGF6 & CTGTGTGGATGGCTACATGG & CCACGGGACTGCCTCTACTA \\
\hline PAQR7 & CAGGAGGTGGCTGAGTTTCT & TAGTCACCTGGCTTTGCCTT \\
\hline JUNB & AGGCTCGGTTTCAGGAGTTT & GAACAGCССТTCTACCACGA \\
\hline CEBPD & СGСТССТАTGTCCCAAGAAA & GGAGAGACTCAGCAACGACC \\
\hline
\end{tabular}

Northern oligo probes

Saunc45B CCTCCGCTGACTAATATGCTT AAATTCAGCGGGTCGCCACG TCTGATCTGAGGTCGCG

EMSA DNA oligos (T7 promoter underlined) Shad1 AACCAATCTCAACCAGCCACTGC CCTATAGTGAGTCGTATTA

CD44v4 TCCTTGTGGTTGTCTGAAGTAGC ACTTCCGGATTTGAATGGCTTG GGTTCCA CTGGGTCCAGT CCTGGTTCCTATAGTGAGTCG TATTA

Universal reverse PCR primer was used for shorter sequence amplifications. For the validations where only a forward sequence is represented, the reverse primer used was the universal qPCR primer. 
polyadenylate the resulting RNA and oligo(DT) primers were used to synthesize the first strand cDNA (Invitrogen). For validation of small RNAs, one universal qPCR reverse primer was used to amplify the poly-dT region of the cDNA along with small RNA specific forward primers (Table 1). Gene-specific primers only were used to validate shyRNAs (Table 1). PCR was performed with input, IgG-associated, and YB-1-associated RNAs. The enrichment of the RNAs by IgG or YB-1 over the input RNA was calculated by subtracting the immunoprecipitated RNA values from the input values. The enrichment of the specific YB-1-associated RNAs over the nonspecific IgG controls were then calculated using the qPCR formula $2^{- \text {(experimental - control) }}$, where the experimental would be the input normalized YB-1 and the control would be the input normalized IgG.

\section{Detection of $5^{\prime}$ phosphate and 3' hydroxyl groups}

RNAs from immunoprecipitation experiments were incubated with Terminator $5^{\prime}$-monophosphate-dependent exonuclease (Epicentre, manufacturer protocol) to probe for the presence of a $5^{\prime}$-monophosphate. After incubation, RNA was purified and used directly for Northern blot. For $3^{\prime}$ hydroxyl modification tests, RNAs were treated with sodium periodate (Alefelder et al. 1998). Briefly, RNA solution was diluted (1:10) in borax/boric acid buffer ( $\mathrm{pH} 8.6)$. One-tenth volume of sodium periodate solution ( $250 \mathrm{mM}$ in water) was added and the mixture was incubated at room temperature for $10 \mathrm{~min}$. After incubation, one-tenth volume of glycerol was added, followed by $10 \mathrm{~min}$ incubation. The mixture was then diluted (1:10) in $\mathrm{NaOH} /$ borax/boric acid buffer $(\mathrm{pH} 9.5)$ and kept at $45^{\circ} \mathrm{C}$ for 90 min. Finally RNA was purified from the mixture using mirVana miRNA Isolation Kit (Applied Biosystems, Foster City, CA). After purification, RNAs were polyadenylated and qRT-PCR was performed as described above.

\section{LNA transfections and shRNA lentivirus infections}

For transfections, cells were plated to $50 \%$ confluency in plates appropriate for downstream experiments. Transfections with $100 \mathrm{nM}$ LNA oligo concentrations were performed for the Shad 1 small and shyRNAs. Transfection for the YB-1 overexpression cell line was performed with $1 \mu \mathrm{g}$ of plasmid DNA (Addgene). All transfections were done in media without antibiotics using Opti-MEM and Lipofectamine LTX with Plus Reagent (Invitrogen). For stable transfections, cells were treated with $200 \mu \mathrm{g} / \mathrm{mL}$ G418 selection $48 \mathrm{~h}$ after transfection. For lentivirus infections, $1 \times 10^{5}$ cells were plates per well in a 6-well plate in complete media for $24 \mathrm{~h}$. Media was replaced with media containing $8 \mu \mathrm{g} / \mathrm{mL}$ polybrene and lentivirus containing either shYB-1 or shScr control plasmids (Santa Cruz). Fresh media containing $2 \mu \mathrm{g} / \mathrm{mL}$ puromycin was added to cells $24 \mathrm{~h}$ postinfection.

\section{Dual fluorescent immunocytochemistry and in situ hybridization}

After heat shock or arsenite treatment, cells were fixed to glass coverslips at room temperature for $10 \mathrm{~min}$ with $4 \%$ paraformaldehyde in 0.1 M PIPES pH 6.9, $2 \mathrm{mM} \mathrm{MgCl}_{2}$, and $1.25 \mathrm{mM}$ EGTA (Geiger and Neugebauer 2005). Coverslips were rinsed in PBS and permea- bilized with $0.2 \%$ Triton X-100 and $\mathrm{MgPBS}$ (10 $\mathrm{mM} \mathrm{MgCl}_{2}$ in PBS) for $10 \mathrm{~min}$ at room temperature. Primary and fluorescent secondary antibodies were diluted according to manufacturer's recommendations in protein block (3\% BSA in PBS). All steps subsequent to secondary antibody incubation were performed in the dark to prevent photobleaching. Antibodies were fixed in $4 \%$ paraformaldehyde for 5 min and rinsed again with MgPBS. For in situ hybridization, coverslips were incubated in prehybridization buffer for $30 \mathrm{~min}$. DIGlabeled LNA probes were diluted 1:100 in the prehybridization buffer and heated for $5 \mathrm{~min}$ at $80^{\circ} \mathrm{C}$. Coverslips were incubated with LNA probes at $60^{\circ} \mathrm{C}$ overnight in a humidified chamber then incubated in $2 \times$ SSC with $50 \%$ formamide at $37^{\circ} \mathrm{C}$ for $30 \mathrm{~min}$. After stringency washes in $2 \times$ and $1 \times$ SSC, coverslips were incubated with the anti-DIG-POD antibody diluted in FISH blocking buffer (0.25\% BSA in $2 \times$ SSC). The antibody was removed with 3-10 min washes in PBST. Tyramide signal amplification (TSA) fluorescent detection was used to detect the DIG-labeled LNA probe. The TSA reagent was diluted 1:50 and applied directly to the coverslip and incubated for $10 \mathrm{~min}$. Coverslips were mounted on slides using VectaShield reagent and slides were imaged using an LSM700 Confocal microscope equipped with a digital camera (Zeiss). Images were analyzed using the Zen 2009 Light Edition Software. Two percent colocalization values were calculated; one was the percentage of PB/SGs that contained both YB-1 and Shad1 staining and one was the percentage of dual labeled YB-1 and Shad1 localized to $\mathrm{PB} / \mathrm{SG}$.

\section{SUPPLEMENTAL MATERIAL}

Supplemental material is available for this article.

\section{ACKNOWLEDGMENTS}

We thank members of the laboratories of D.B.DeF. and B.J. for helpful discussions. We also thank Drs. Paula Grabowski and Mark Nichols for valuable advice. This work was primarily supported by the G. Harold and Leila Y. Mathers Foundation (B.J.), and partly by National Institutes of Health (GM079756 to B.J.) and American Cancer Society (RSG-09-054-01 to B.J.), Deutsche Forschungsgemeinschaft (SFB 960 to G.M.), the European Research Council (ERC grant "sRNAs" to G.M.), and the Bavarian Genome Research Network (BayGene to G.M.).

Received March 26, 2014; accepted March 3, 2015.

\section{REFERENCES}

Agafonov DE, Deckert J, Wolf E, Odenwälder P, Bessonov S, Will CL, Urlaub H, Lührmann R. 2011. Semiquantitative proteomic analysis of the human spliceosome via a novel two-dimensional gel electrophoresis method. Mol Cell Biol 31: 2667-2682.

Alefelder S, Patel BK, Eckstein F. 1998. Incorporation of terminal phosphorothioates into oligonucleotides. Nucleic Acids Res 26: 4983-4988.

Bargou RC, Jürchott K, Wagener C, Bergmann S, Metzner S, Bommert K, Mapara MY, Winzer KJ, Dietel M, Dörken B, et al. 1997. Nuclear localization and increased levels of transcription factor YB-1 in primary human breast cancers are associated with intrinsic MDR1 gene expression. Nat Med 3: 447-450. 
Bensalah K, Lotan Y, Karam JA, Shariat SF. 2008. New circulating biomarkers for prostate cancer. Prostate Cancer Prostatic Dis 11: 112120.

Busund LT, Richardsen E, Busund R, Ukkonen T, Bjørnsen T, Busch C, Stalsberg H. 2005. Significant expression of IGFBP2 in breast cancer compared with benign lesions. J Clin Pathol 58: 361-366.

Christov CP, Gardiner TJ, Szüts D, Krude T. 2006. Functional requirement of noncoding Y RNAs for human chromosomal DNA replication. Mol Cell Biol 26: 6993-7004.

Deckert J, Hartmuth K, Boehringer D, Behzadnia N, Will CL, Kastner B, Stark H, Urlaub H, Lührmann R. 2006. Protein composition and electron microscopy structure of affinity-purified human spliceosomal B complexes isolated under physiological conditions. Mol Cell Biol 26: 5528-5543.

Didier DK, Schiffenbauer J, Woulfe SL, Zacheis M, Schwartz BD. 1988. Characterization of the CDNA encoding a protein binding to the major histocompatibility complex class II Y box. Proc Natl Acad Sci 85: $7322-7326$.

Dutertre M, Sanchez G, De Cian MC, Barbier J, Dardenne E, Gratadou L, Dujardin G, Le Jossic-Corcos C, Corcos L, Auboeuf D. 2010. Cotranscriptional exon skipping in the genotoxic stress response. Nat Struct Mol Biol 17: 1358-1366.

Evdokimova V, Ruzanov P, Imataka H, Raught B, Svitkin Y, Ovchinnikov LP, Sonenberg N. 2001. The major mRNA-associated protein YB-1 is a potent $5^{\prime}$ cap-dependent mRNA stabilizer. $E M B O J$ 20: 5491-5502.

Evdokimova V, Ruzanov P, Anglesio MS, Sorokin AV, Ovchinnikov LP, Buckley J, Triche TJ, Sonenberg N, Sorensen PH. 2006. Akt-mediated YB-1 phosphorylation activates translation of silent mRNA species. Mol Cell Biol 26: 277-292.

Evdokimova V, Tognon C, Ng T, Ruzanov P, Melnyk N, Fink D, Sorokin A, Ovchinnikov LP, Davicioni E, Triche TJ, et al. 2009a. Translational activation of snail 1 and other developmentally regulated transcription factors by YB-1 promotes an epithelial-mesenchymal transition. Cancer Cell 15: 402-415.

Evdokimova V, Tognon C, Ng T, Sorensen PH. 2009b. Reduced proliferation and enhanced migration: two sides of the same coin? Molecular mechanisms of metastatic progression by YB-1. Cell Cycle 8: 2901-2906.

Garand C, Guay D, Sereduk C, Chow D, Tsofack SP, Langlois M, Perreault E, Yin HH, Lebel M. 2011. An integrative approach to identify YB-1-interacting proteins required for cisplatin resistance in MCF7 and MDA-MB-231 breast cancer cells. Cancer Sci 102: $1410-1417$.

Geiger JA, Neugebauer KM. 2005. Fluorescent detection of nascent transcripts and RNA-binding proteins in cell nuclei. In Handbook of RNA biochemistry (ed. Hartmann RK, et al.), Vol. 2, pp. 729-736. Wiley-VCH Verlag GmbH, Weinheim, Germany.

Gentleman RC, Carey VJ, Bates DM, Bolstad B, Dettling M, Dudoit S, Ellis B, Gautier L, Ge Y, Gentry J, et al. 2004. Bioconductor: open software development for computational biology and bioinformatics. Genome Biol 5: R80.

Giménez-Bonafé P, Fedoruk MN, Whitmore TG, Akbari M, Ralph JL, Ettinger S, Gleave ME, Nelson CC. 2004. YB-1 is upregulated during prostate cancer tumor progression and increases P-glycoprotein activity. Prostate 59: 337-349.

Girard A, Sachidanandam R, Hannon GJ, Carmell MA. 2006. A germline-specific class of small RNAs binds mammalian Piwi proteins. Nature 442: 199-202.

Grant CE, Bailey TL, Noble WS. 2011. FIMO: scanning for occurrences of a given motif. Bioinformatics 27: 1017-1018.

Gupta S, Stamatoyannopoulos JA, Bailey TL, Noble WS. 2007. Quantifying similarity between motifs. Genome Biol 8: R24.

Gupta RA, Shah N, Wang KC, Kim J, Horlings HM, Wong DJ, Tsai MC, Hung T, Argani P, Rinn JL, et al. 2010. Long non-coding RNA HOTAIR reprograms chromatin state to promote cancer metastasis. Nature 464: 1071-1076.

Habibi G, Leung S, Law JH, Gelmon K, Masoudi H, Turbin D, Pollak M, Nielsen TO, Huntsman D, Dunn SE. 2008. Redefining prognostic factors for breast cancer: YB-1 is a stronger predictor of relapse and disease-specific survival than estrogen receptor or HER-2 across all tumor subtypes. Breast Cancer Res 10: R86.

Hammond SM, Boettcher S, Caudy AA, Kobayashi R, Hannon GJ. 2001. Argonaute2, a link between genetic and biochemical analyses of RNAi. Science 293: 1146-1150.

Hartman ZC, Yang XY, Glass O, Lei G, Osada T, Dave SS, Morse MA, Clay TM, Lyerly HK. 2011. HER2 overexpression elicits a proinflammatory IL-6 autocrine signaling loop that is critical for tumorigenesis. Cancer Res 71: 4380-4391.

Höck J, Weinmann L, Ender C, Rüdel S, Kremmer E, Raabe M, Urlaub H, Meister G. 2007. Proteomic and functional analysis of Argonaute-containing mRNA-protein complexes in human cells. EMBO Rep 8: 1052-1060.

Ise T, Nagatani G, Imamura T, Kato K, Takano H, Nomoto M, Izumi H, Ohmori H, Okamoto T, Ohga T, et al. 1999. Transcription factor Ybox binding protein 1 binds preferentially to cisplatin-modified DNA and interacts with proliferating cell nuclear antigen. Cancer Res 59: 342-346.

Kanety H, Madjar Y, Dagan Y, Levi J, Papa MZ, Pariente C, Goldwasser B, Karasik A. 1993. Serum insulin-like growth factorbinding protein-2 (IGFBP-2) is increased and IGFBP-3 is decreased in patients with prostate cancer: correlation with serum prostatespecific antigen. J Clin Endocrinol Metab 77: 229-233.

Kapranov P, Cheng J, Dike S, Nix DA, Duttagupta R, Willingham AT, Stadler PF, Hertel J, Hackermüller J, Hofacker IL, et al. 2007. RNA maps reveal new RNA classes and a possible function for pervasive transcription. Science 316: 1484-1488.

Karolchik D, Hinrichs AS, Kent WJ. 2009. The UCSC genome browser. Curr Protoc Bioinformatics Chapter 1: Unit 1.4. doi: 10.1002/ 0471250953.bi0104s28.

Kedersha N, Anderson P. 2007. Mammalian stress granules and processing bodies. Methods Enzymol 431: 61-81.

Kim SW, Li Z, Moore PS, Monaghan AP, Chang Y, Nichols M, John B. 2010. A sensitive non-radioactive northern blot method to detect small RNAs. Nucleic Acids Res 38: e98.

Kohno K, Izumi H, Uchiumi T, Ashizuka M, Kuwano M. 2003. The pleiotropic functions of the Y-box-binding protein, YB-1. Bioessays 25: 691-698.

Krude T, Christov CP, Hyrien O, Marheineke K. 2009. Y RNA functions at the initiation step of mammalian chromosomal DNA replication. J Cell Sci 122: 2836-2845.

Lai F, Orom UA, Cesaroni M, Beringer M, Taatjes DJ, Blobel GA, Shiekhattar R. 2013. Activating RNAs associate with Mediator to enhance chromatin architecture and transcription. Nature 494: 497-501.

Lee YS, Shibata Y, Malhotra A, Dutta A. 2009. A novel class of small RNAs: tRNA-derived RNA fragments (tRFs). Genes Dev 23: 2639-2649.

Lin Y, Jiang T, Zhou K, Xu L, Chen B, Li G, Qiu X, Zhang W, Song SW. 2009. Plasma IGFBP-2 levels predict clinical outcomes of patients with high-grade gliomas. Neuro Oncol 11: 468-476.

Lin Y, Li Z, Ozsolak F, Kim SW, Arango-Argoty G, Liu TT, Tenenbaum SA, Bailey T, Monaghan AP, Milos PM, et al. 2012. An in-depth map of polyadenylation sites in cancer. Nucleic Acids Res 40: 8460-8471.

Meiri E, Levy A, Benjamin H, Ben-David M, Cohen L, Dov A, Dromi N, Elyakim E, Yerushalmi N, Zion O, et al. 2010. Discovery of microRNAs and other small RNAs in solid tumors. Nucleic Acids Res 38: 6234-6246.

Meister G, Landthaler M, Dorsett Y, Tuschl T. 2004. Sequence-specific inhibition of microRNA- and siRNA-induced RNA silencing. RNA 10: 544-550.

Moss EG, Tang L. 2003. Conservation of the heterochronic regulator Lin-28, its developmental expression and microRNA complementary sites. Dev Biol 258: 432-442.

Ozsolak F, Kapranov P, Foissac S, Kim SW, Fishilevich E, Monaghan AP, John B, Milos PM. 2010. Comprehensive polyadenylation site maps 
in yeast and human reveal pervasive alternative polyadenylation. Cell 143: 1018-1029.

Pang Y, Young CY, Yuan H. 2010. MicroRNAs and prostate cancer. Acta Biochim Biophys Sin (Shanghai) 42: 363-369.

Preker P, Nielsen J, Kammler S, Lykke-Andersen S, Christensen MS, Mapendano CK, Schierup MH, Jensen TH. 2008. RNA exosome depletion reveals transcription upstream of active human promoters. Science 322: 1851-1854.

Raffetseder U, Frye B, Rauen T, Jürchott K, Royer HD, Jansen PL, Mertens PR. 2003. Splicing factor SRp30c interaction with Y-box protein-1 confers nuclear YB-1 shuttling and alternative splice site selection. J Biol Chem 278: 18241-18248.

Shariat SF, Lamb DJ, Kattan MW, Nguyen C, Kim J, Beck J, Wheeler TM, Slawin KM. 2002. Association of preoperative plasma levels of insulin-like growth factor I and insulin-like growth factor binding proteins- 2 and -3 with prostate cancer invasion, progression, and metastasis. J Clin Oncol 20: 833-841.

Sibley CR, Seow Y, Saayman S, Dijkstra KK, El Andaloussi S, Weinberg MS, Wood MJ. 2011. The biogenesis and characterization of mammalian microRNAs of mirtron origin. Nucleic Acids Res 40: $438-448$.

Sorlie T, Tibshirani R, Parker J, Hastie T, Marron JS, Nobel A, Deng S, Johnsen H, Pesich R, Geisler S, et al. 2003. Repeated observation of breast tumor subtypes in independent gene expression data sets. Proc Natl Acad Sci 100: 8418-8423.

Spitkovsky DD, Royer-Pokora B, Delius H, Kisseljov F, Jenkins NA, Gilbert DJ, Copeland NG, Royer HD. 1992. Tissue restricted expression and chromosomal localization of the YB-1 gene encoding a $42 \mathrm{kD}$ nuclear CCAAT binding protein. Nucleic Acids Res 20: 797-803.

Stickeler E, Fraser SD, Honig A, Chen AL, Berget SM, Cooper TA. 2001. The RNA binding protein $\mathrm{YB}-1$ binds $\mathrm{A} / \mathrm{C}$-rich exon enhancers and stimulates splicing of the CD44 alternative exon v4. EMBO J 20: $3821-3830$.
Taft RJ, Glazov EA, Lassmann T, Hayashizaki Y, Carninci P, Mattick JS. 2009. Small RNAs derived from snoRNAs. RNA 15: 1233-1240.

Valen E, Preker P, Andersen PR, Zhao X, Chen Y, Ender C, Dueck A, Meister G, Sandelin A, Jensen TH. 2011. Biogenic mechanisms and utilization of small RNAs derived from human protein-coding genes. Nat Struct Mol Biol 18: 1075-1082.

Van de Putte T, Maruhashi M, Francis A, Nelles L, Kondoh H, Huylebroeck D, Higashi Y. 2003. Mice lacking $Z f h x 1 b$, the gene that codes for Smad-interacting protein-1, reveal a role for multiple neural crest cell defects in the etiology of Hirschsprung diseasemental retardation syndrome. Am J Hum Genet 72: 465-470.

Viswanathan SR, Powers JT, Einhorn W, Hoshida Y, Ng TL, Toffanin S, O'Sullivan M, Lu J, Phillips LA, Lockhart VL, et al. 2009. Lin28 promotes transformation and is associated with advanced human malignancies. Nat Genet 41: 843-848.

Walter BA, Valera VA, Pinto PA, Merino MJ. 2013. Comprehensive microRNA profiling of prostate cancer. J Cancer 4: 350-357.

Wang X, Lee SO, Xia S, Jiang Q, Luo J, Li L, Yeh S, Chang C. 2013. Endothelial cells enhance prostate cancer metastasis via IL-6 $\rightarrow$ androgen receptor $\rightarrow$ TGF- $\beta \rightarrow$ MMP-9 signals. Mol Cancer Ther 12: 1026-1037.

Wu L, Fan J, Belasco JG. 2006. MicroRNAs direct rapid deadenylation of mRNA. Proc Natl Acad Sci 103: 4034-4039.

Yilmaz M, Maass D, Tiwari N, Waldmeier L, Schmidt P, Lehembre F, Christofori G. 2011. Transcription factor Dlx2 protects from TGF $\beta$-induced cell-cycle arrest and apoptosis. EMBO J 30: 4489-4499.

Yu J, Vodyanik MA, Smuga-Otto K, Antosiewicz-Bourget J, Frane JL, Tian S, Nie J, Jonsdottir GA, Ruotti V, Stewart R, et al. 2007. Induced pluripotent stem cell lines derived from human somatic cells. Science 318: 1917-1920.

Zhang YF, Homer C, Edwards SJ, Hananeia L, Lasham A, Royds J, Sheard P, Braithwaite AW. 2003. Nuclear localization of Y-box factor YB1 requires wild-type p53. Oncogene 22: 2782-2794. 

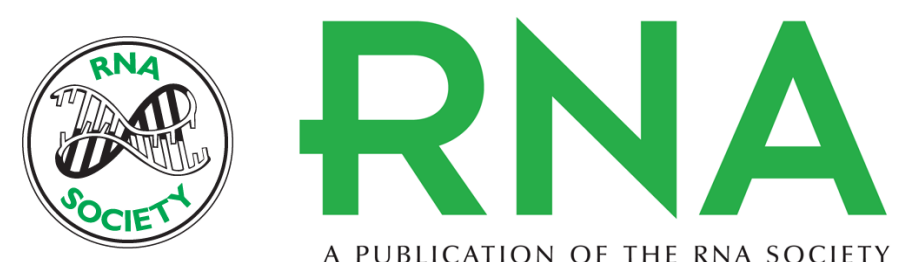

A PUBLICATION OF THE RNA SOCIETY

\section{Noncoding RNAs that associate with YB-1 alter proliferation in prostate cancer cells}

Teresa T. Liu, Gustavo Arango-Argoty, Zhihua Li, et al.

RNA 2015 21: 1159-1172 originally published online April 22, 2015

Access the most recent version at doi:10.1261/rna.045559.114

\section{Supplemental http://rnajournal.cshlp.org/content/suppl/2015/04/03/rna.045559.114.DC1 \\ Material}

References This article cites 59 articles, 24 of which can be accessed free at: http://rnajournal.cshlp.org/content/21/6/1159.full.html\#ref-list-1

Creative This article is distributed exclusively by the RNA Society for the first 12 months after the Commons

License full-issue publication date (see http://rnajournal.cshlp.org/site/misc/terms.xhtml). After 12 months, it is available under a Creative Commons License (Attribution-NonCommercial 4.0 International), as described at http://creativecommons.org/licenses/by-nc/4.0/.

Email Alerting
Service

Receive free email alerts when new articles cite this article - sign up in the box at the top right corner of the article or click here. 